\title{
Influence of Preharvest Gibberellic Acid Treatments on Postharvest Quality of Minimally Processed Leaf Lettuce and Rocket
}

\author{
Alessandro Miceli *(D), Filippo Vetrano, Leo Sabatino ${ }^{\mathbb{D}}$, Fabio D’Anna and Alessandra Moncada \\ Dipartimento Scienze Agrarie, Alimentari e Forestali, Università di Palermo, Viale delle Scienze 4, \\ 90128 Palermo, Italy \\ * Correspondence: alessandro.miceli@unipa.it; Tel.: +39-091-2386-2219
}

Received: 10 June 2019; Accepted: 23 August 2019; Published: 2 September 2019

\begin{abstract}
Plant growth regulators are used in high-value vegetable crops during cultivation and after harvest to increase yield, enhance crop management, and improve or retain the produce quality. The aim of this work was to evaluate the quality characteristics during cold storage of minimally processed leaf lettuce and rocket, obtained from plants grown in a hydroponic floating system with mineral nutrient solutions (MNS) containing different levels of gibberellic acid $\left(\mathrm{GA}_{3}\right)$. Plants were grown in greenhouse conditions on nutrient solutions containing $0,10^{-8}$, and $10^{-6} \mathrm{M} \mathrm{GA}_{3}$. At harvest, lettuce and rocket were immediately processed as fresh-cut vegetables and stored for $21 \mathrm{~d}$ at $4{ }^{\circ} \mathrm{C}$. After processing, weight loss, total soluble solids, titratable acidity, ascorbic acid and nitrate content, leaf color characteristics, and overall quality were evaluated. Adding $10^{-6} \mathrm{M} \mathrm{GA}_{3}$ to the MNS of a floating system significantly increased the yield of leaf lettuce and rocket plants and of minimally-processed leaves. In addition, preharvest $\mathrm{GA}_{3}$ treatments had positive effects on delaying senescence and enhancing shelf-life of minimally processed lettuce and rocket. The slowed senescence of $\mathrm{GA}_{3}$-treated samples maintained an overall quality over the threshold of marketability in both lettuce and rocket for up to $21 \mathrm{~d}$ of cold storage.
\end{abstract}

Keywords: postharvest; minimally processed vegetables; gibberellic acid; $\mathrm{GA}_{3}$; hydroponics; floating system; leafy vegetables; leaf lettuce; rocket; nitrate content; ascorbic acid; shelf life

\section{Introduction}

In recent years, interest and demand for minimally processed vegetables has increased dramatically worldwide, and leafy vegetables have achieved great economic importance in the global market. In fact, the increase in demand for vegetables over the past 25 years has led to the global value of trade in vegetables exceeding that of cereals [1]. This trend is due to the growing interest of consumers for healthy foods [2-5], and their awareness of the role of fresh fruits and vegetables in reducing the risk of cancers as well as many other degenerative diseases [6,7]. Moreover, the modern frenetic lifestyle has increased the demand for healthy foods characterized by high convenience of use, which resulted in the success of minimally processed vegetables $[8,9]$.

Among vegetables, ready-to-eat (RTE) products are those that are increasing most rapidly [10], even in developing countries [11]. Thus, the demand for raw vegetables for RTE production is also increasing, which necessitates finding new cultivation systems and techniques that can supply a sufficient amount of high-quality vegetables and enhance quality retention after minimal processing and during postharvest storage. Thus, it would be highly worthwhile to find new ways to improve the productivity and postharvest quality of vegetable crops with cost-effective and easy-to-use techniques, while at the same time limiting the impact on the environment and reducing food waste [12-16]. 
Genetic improvement, innovative cultivation systems, and use of plant-growth regulators (PGRs) could help in reaching these goals. PGRs are used in high-value horticultural crops (e.g., tomato, eggplant, strawberry, artichoke, etc.) during cultivation, as well as during postharvest management to increase yield, enhance crop management, and improve the quality of produce [17]. The use of PGRs, particularly gibberellins (GAs), has gained a renewed interest, as they address improper source-sink relationships and plant hormonal imbalances that may occur during growth [18]. GAs are essential growth hormones found in plants and fungi and have several effects on plant development. They can promote stem and root elongation, leaf expansion, flowering, fruit senescence, seed germination or dormancy, and so on [19]. Exogenous applications of GAs have actively influenced many physiological activities such as vegetative growth, flowering and flower morphology, earliness, fruit set, ion transport and osmoregulation, leaf area expansion, and internode elongation. GAs have also increased biomass production, fruit weight, and dry matter production [20-29], and have been used to control and slow down postharvest changes in fruits, vegetables, and flowers [30-33]. These effects are, in some cases, controversial as they can differ considerably depending on hormone demand, relative concentrations, and plant responses at various physiological and growth stages [34]. The use of gibberellic acid $\left(\mathrm{GA}_{3}\right)$ to improve crop productivity or to control postharvest quality has been tested on many fruits and vegetables [18,30-33,35-41]. Nevertheless, the effects of preharvest treatment with this phytohormone on postharvest characteristics of leafy vegetables still needs to be further investigated. In a previous study, we investigated the effect of suppling low levels of $\mathrm{GA}_{3}\left(0,10^{-8}, 10^{-6}\right.$, and $\left.10^{-4} \mathrm{M} \mathrm{GA}_{3}\right)$ to leaf lettuce and rocket plants through the mineral nutrient solution of a hydroponic floating system and evaluated their effects on growth and quality, showing that the addition of $10^{-6} \mathrm{M} \mathrm{GA}_{3}$ to the nutrient solution of a hydroponic floating system can promote growth and quality of lettuce and rocket plants at harvest [42]. The exogenous supply of $\mathrm{GA}_{3}$ during plant growth might also exert some effects on postharvest life of vegetables that are worth investigating. Therefore, the aim of this work was to evaluate the quality characteristics during cold storage of minimally processed leaf lettuce and rocket, obtained from plants grown in a hydroponic floating system with mineral nutrient solutions containing different levels of $\mathrm{GA}_{3}$.

\section{Materials and Methods}

\subsection{Leafy Vegetable Cultivation}

This study was carried out in greenhouse conditions at the Department of Agricultural, Food, and Forest Sciences (SAAF-University of Palermo, Palermo, Italy) ( $38^{\circ} 6^{\prime} 28^{\prime \prime} \mathrm{N} 13^{\circ} 21^{\prime} 3^{\prime \prime}$ E; altitude $\left.49 \mathrm{~m}\right)$ using a hydroponic floating cultivation system. Plants were grown under natural light conditions; the mean air temperature was $20^{\circ} \mathrm{C}$, varying between 12 and $27^{\circ} \mathrm{C}$, and relative humidity averaged $69 \%$. A mineral nutrient solution (MNS) was used, with $4.5 \mathrm{mM} \mathrm{Ca}^{2+}, 2 \mathrm{mM} \mathrm{H}_{2} \mathrm{PO}_{4}^{-}, 1.25 \mathrm{mM} \mathrm{NH}_{4}{ }^{+}$, $1 \mathrm{mM} \mathrm{Mg}^{2+}, 19 \mathrm{mM} \mathrm{NO}_{3}{ }^{-}, 11 \mathrm{mM} \mathrm{K}^{+}, 1.1 \mathrm{mM} \mathrm{SO}_{4}{ }^{2-}, 40 \mu \mathrm{M} \mathrm{Fe}^{3+}, 5 \mu \mathrm{M} \mathrm{Mn}^{2+}, 4 \mu \mathrm{M} \mathrm{Zn}^{2+}, 30 \mu \mathrm{M}$ $\mathrm{BO}_{3}{ }^{3-}, 0.75 \mu \mathrm{M} \mathrm{Cu}^{2+}$, and $0.50 \mu \mathrm{M} \mathrm{Mo}$ [43] in tap water (electrical conductivity (EC) $480 \mu \mathrm{S} \mathrm{cm}{ }^{-1}$; $\mathrm{pH}$ 7.7). MNS was then mixed with gibberellic acid (Gibrelex, Biolchim, Bologna, Italy), selected from a previous study [42], to create three concentrations: $0,10^{-8}$, and $10^{-6} \mathrm{M} \mathrm{GA}_{3}$. The EC of the MNS was $2.25 \mathrm{mS} \mathrm{cm}^{-1}$, and the $\mathrm{pH}$ was 5.8 .

Plantlets with 3-4 true leaves of leaf lettuce (Lactuca sativa L. var. Crispa cv. 'Lattuga da Taglio a Foglia Liscia', Sementi Dotto-SDD SPA, Udine, Italy) and rocket (Eruca sativa L. cv. 'Coltivata da orto', Sementi Dotto-SDD SPA, Udine, Italy), were transplanted (13 March) into drilled polystyrene panels $\left(400\right.$ plants $\left.\mathrm{m}^{-2}\right)$ that were then placed to float in tubs $(100 \mathrm{~cm}$ long $\times 50 \mathrm{~cm}$ wide $\times 15 \mathrm{~cm}$ deep, containing $75 \mathrm{~L}$ of treatment solution). Each treatment consisted of four replicated tubs for each $\mathrm{GA}_{3}$ concentration (12 tubs for each leafy vegetable). Leaf lettuce and rocket have a short crop cycle, so it was not necessary to aerate the nutrient solutions during plant growth [44]. The MNS was monitored every day for water consumption and every week for $\mathrm{EC}$ and $\mathrm{pH}$. The tubs were replenished with new MNS with the same $\mathrm{GA}_{3}$ concentration when the volume of MNS inside them dropped by $20 \%$. 
At harvest (21 d after transplanting), all plants were collected, and marketable yield was calculated.

\subsection{Minimal Processing and Cold Storage}

Soon after harvesting, plants were transferred to the laboratory of Vegetable Analysis of the SAAF Department and immediately processed, using common practices for fresh-cut production. Leaves were removed from stalks, and those with defects, yellowing, or decay were discarded. Then, they were washed twice with tap water for $5 \mathrm{~min}$, and dried for $1 \mathrm{~min}$ with a handheld salad spinner by manual centrifugation. At the end of processing, the yield of minimally processed product was determined.

Samples of $100 \mathrm{~g}$ of each $\mathrm{GA}_{3}$ treatment and each leafy vegetable were immediately packed in PE bags, sealed with a hot bar (Laica VT3112, Vicenza, Italy), and kept at $4{ }^{\circ} \mathrm{C}$ for $21 \mathrm{~d}$. At the end of processing and after 7,14 , and $21 \mathrm{~d}$ of cold storage, the physicochemical characteristics of randomly selected samples were assessed. Weight loss was estimated by weighing samples soon after processing

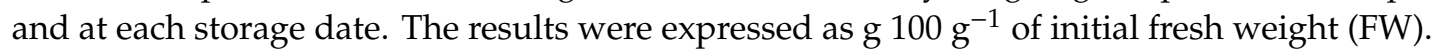

Overall quality (OQ) was evaluated by an informal panel consisting of twelve people (seven men and five women, aged 24-60) using a 1 to 5 scale, in which $5=$ excellent or having a freshly harvested appearance and full visual and sensory acceptability (e.g., no yellowing or browning, free from any off odors, defects, and decay), 3 = fair/still acceptable and marketable (e.g., appearance of minor defects or moderate color alteration), and $1=$ poor/unmarketable, presence of off odors, extensive color changes, and major defects or decay symptoms.

Leaf color was measured on the upper side of ten randomly selected leaves (two points of photosynthetic tissue per leaf) for each sample using a colorimeter (Chroma-meter CR-400, Minolta Corp., Ltd., Osaka, Japan). The instrument recorded the CIELAB color components L* (lightness), a* (positive values for reddish colors and negative values for greenish colors), and $\mathrm{b}^{*}$ (positive values for yellowish colors and negative values for bluish colors). From $\mathrm{a}^{*}$ and $\mathrm{b}^{*}$ values, hue angle $\left(\mathrm{h}^{\circ}\right)$ and Chroma $\left(C^{*}\right)$ were calculated as $h^{\circ}=180^{\circ}+\arctan \left(b^{*} / a^{*}\right)[45]$ and $C^{*}=\left(a^{* 2}+b^{* 2}\right)^{1 / 2}$.

Twenty grams of each sample were then homogenized with $\mathrm{H}_{2} \mathrm{O}(1: 2 \mathrm{w} / \mathrm{v})$, and the homogenates were centrifuged at $3500 \mathrm{rpm}$ for $10 \mathrm{~min}$. The supernatants were analyzed to determine total soluble solids (TSS), titratable acidity (TA), and ascorbic acid and nitrate content. TSS was determined in ${ }^{\circ}$ Brix using a digital refractometer (MTD-045nD, Three-In-One Enterprises Co. Ltd., New Taipei City, Taiwan). TA was calculated by titrating $10 \mathrm{~mL}$ of extract with $0.1 \mathrm{M} \mathrm{NaOH}$ up to $\mathrm{pH} 8.1$ and expressed as $\mathrm{mg}$ of citric acid per $100 \mathrm{~g}$ of fresh weight (FW). Ascorbic acid and nitrate contents (respectively, as $\mathrm{mg} 100 \mathrm{~g}^{-1}$ and $\mathrm{mg} \mathrm{kg}^{-1} \mathrm{FW}$ ) were determined reflectometrically using a Reflectometer RQflex10 Reflectoquant and the Reflectoquant ascorbic acid and nitrate test strips (Merck, Darmstadt, Germany) (procedures described in art. 1.16971 .0001 and 1.16981 .0001 by Merck [46]).

\subsection{Statistics and Principal Component Analysis}

A completely randomized design with four replicates per treatment was performed. To determine the effect of the $\mathrm{GA}_{3}$ level on yield of each leafy vegetable, a one-way ANOVA was performed (for replicated tubs for each $\mathrm{GA}_{3}$ level). Differences between means were determined by Tukey's multiple-range test at $P \leq 5 \%$. The effect of $\mathrm{GA}_{3}$ concentration and storage time on each leafy vegetable was determined, performing a two-way ANOVA (for replicated bags for each $\mathrm{GA}_{3}$ level and each storage time). Mean values were compared by the least significant differences (LSD) test at $P \leq 5 \%$ to identify significant differences among treatments and significant interactions between factors.

Principal component analysis (PCA) was performed on morpho-physiological and phytochemical parameters to determine the dominant parameters that were most effective in discriminating between preharvest $\mathrm{GA}_{3}$ treatments and storage time (SPSS version 13.0 (SPSS Inc., Chicago, IL, USA) statistical software). The input matrix for the analysis consisted of weight loss, TSS, TA, ascorbic acid and $\mathrm{N}-\mathrm{NO}_{3}{ }^{-}$content, $\mathrm{L}^{*}, \mathrm{a}^{*}, \mathrm{~b}^{*}$, Chroma, Hue angle, and overall quality (OQ). The optimum number of principal components (PCs) was assessed, retaining factors with eigenvalues higher than 1.0. The first and second principal components (PCs) were used to determine the score plot and loading matrix. 


\section{Results}

\subsection{Leaf Lettuce}

Leaf lettuce grown without gibberellic acid $\left(\mathrm{GA}_{3}\right)$ yielded $4.7 \mathrm{~kg} \mathrm{~m}^{-2}$; the addition of $\mathrm{GA}_{3}$ to the MNS at the highest concentration $\left(10^{-6} \mathrm{M}\right)$ significantly increased the yield by $2.3 \mathrm{~kg} \mathrm{~m}^{-2}(+48.5 \%)$ but did not significantly affect the percentage yield of minimally processed leaves, which was $85.4 \%$ on average (Table 1). Hence, the production of fresh-cut leaves ranged in $\mathrm{kg} \mathrm{m}^{-2}$ from 4.0 to 5.9 for control and $10^{-6} \mathrm{M} \mathrm{GA}_{3}$, respectively (Table 1).

Table 1. Crop and minimal processing yield of leaf lettuce and rocket plants grown in mineral nutrient solutions with different levels of gibberellic acid $\left(\mathrm{GA}_{3}\right)$.

\begin{tabular}{cccc}
\hline \multirow{2}{*}{ Yield } & \multicolumn{3}{c}{$\mathbf{G A}_{\mathbf{3}}(\mathbf{M})$} \\
\cline { 2 - 4 } & $\mathbf{0}$ & $\mathbf{1 0}^{-\mathbf{8}}$ & $\mathbf{1 0}^{-\mathbf{6}}$ \\
\hline & Leaf Lettuce \\
\hline Crop yield $\left(\mathrm{kg} \mathrm{m}^{-2}\right)$ & $4.7 \mathrm{~b}^{\mathrm{z}}$ & $5.2 \mathrm{~b}$ & $7.0 \mathrm{a}$ \\
Minimal processing yield $(\%)$ & $84.6 \mathrm{a}$ & $86.6 \mathrm{a}$ & $85.0 \mathrm{a}$ \\
Minimal processing yield $\left(\mathrm{kg} \mathrm{m}^{-2}\right)$ & $4.0 \mathrm{~b}$ & $4.5 \mathrm{~b}$ & $5.9 \mathrm{a}$ \\
\hline & Rocket & \\
\hline Crop yield $\left(\mathrm{kg} \mathrm{m}^{-2}\right)$ & $2.9 \mathrm{~b}$ & $3.1 \mathrm{a}$ \\
Minimal processing yield $(\%)$ & $70.6 \mathrm{a}$ & $71.4 \mathrm{a}$ \\
Minimal processing yield $\left(\mathrm{kg} \mathrm{m}^{-2}\right)$ & $2.0 \mathrm{~b}$ & $2.3 \mathrm{a}$ & $2.9 \mathrm{a}$ \\
\hline Results are the mean value of four replicates. Data within a row followed by the same letter are not significantly
\end{tabular}

The weight loss of minimally processed leaf lettuce was not affected by the $\mathrm{GA}_{3}$ treatments, but it increased significantly during storage (Table 2). Fresh-cut produce retained a high water content until

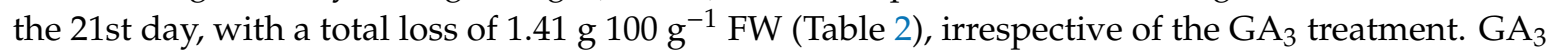
treatments did not affect TSS, titratable acidity, and ascorbic acid content at harvest, and no significant interaction was found with storage time, but the highest concentration of $\mathrm{GA}_{3}\left(10^{-6} \mathrm{M}\right)$ significantly reduced the nitrate content of lettuce leaves $\left(-23.8 \% ; 1944.8 \mathrm{mg} \mathrm{kg}^{-1} \mathrm{FW}\right)$ compared with the control ( $\left.2553.3 \mathrm{mg} \mathrm{kg}^{-1} \mathrm{FW}\right)$. This reduction of nitrate content occurred during cold storage, since immediately after processing, the leaves of the different treatments had a similar nitrate content $\left(2443.0 \mathrm{mg} \mathrm{kg}^{-1} \mathrm{FW}\right.$ on average). All the examined chemical parameters retained their initial values without significant changes, except TSS, which increased from an initial value of $2.8^{\circ}$ Brix to $3.3^{\circ}$ Brix by the 21 st day.

Color measurements during storage showed major changes induced by $\mathrm{GA}_{3}$ only for lightness $\left(\mathrm{L}^{*}\right)$ and yellowness $\left(\mathrm{b}^{*}\right)$, while storage affected all measured or calculated color parameters (Table 3 ). Soon after processing, the leaves of $\mathrm{GA}_{3}$ treatments had a lower $\mathrm{L}^{*}$ than the controls; the latter recorded no significant change during storage, whereas $\mathrm{GA}_{3}$ leaves increased their lightness up to levels similar to the control (Table 3).

Increasing $\mathrm{GA}_{3}$ concentration from 0 up to the highest level $\left(10^{-6} \mathrm{M}\right)$ resulted in a slight yet significant reduction of $b^{*}$ values (39.4 and 38.7, respectively). During storage, minimally processed lettuce leaves showed an opposite trend of $a^{*}$ and $b^{*}$ values; the first decreased significantly in the final part of the storage period, whereas $b^{*}$ increased throughout cold storage from 38.2 to 39.6 for 0 and $21 \mathrm{~d}$, respectively. Consequently, the chroma (vividness) of minimally processed leaves increased significantly after the first week of storage (from 44.0 at day 0 to 44.8 on average after the 7 th day), and the hue angle decreased linearly $\left(\mathrm{R}^{2}=0.971\right)$ from $119.8(0 \mathrm{~d})$ to $118.2(21 \mathrm{~d})$ (Table 3).

Scores for overall quality (OQ) of leaf lettuce decreased during storage, but the samples of the $10^{-6} \mathrm{M} \mathrm{GA}_{3}$ treatment showed a significantly higher visual quality than the controls (Table 3); both GA 3 treatments maintained an acceptability score above the limit of marketability until day 21 , whereas 
the score of the control samples dropped just below this threshold at the end of the storage period (Figure 1).

Table 2. Effect of $\mathrm{GA}_{3}$ and storage duration (d) on weight loss, total soluble solids (TSS), titratable acidity (TA), and ascorbic acid and nitrate content of minimally processed leaf lettuce.

\begin{tabular}{|c|c|c|c|c|c|c|}
\hline \multicolumn{2}{|c|}{ Treatments } & $\begin{array}{l}\text { Weight Loss } \\
\text { (g } 100 \mathrm{~g}^{-1} \text { FW) }\end{array}$ & $\begin{array}{c}\text { TSS } \\
\left({ }^{\circ} \text { Brix }\right)\end{array}$ & $\begin{array}{c}\mathrm{TA}^{\mathrm{y}} \\
\left(\mathrm{mg} 100 \mathrm{~g}^{-1} \mathrm{FW}\right)\end{array}$ & $\begin{array}{l}\text { Ascorbic Acid } \\
\left(\mathrm{mg} 100 \mathrm{~g}^{-1} \mathrm{FW}\right)\end{array}$ & $\begin{array}{c}\mathrm{N}-\mathrm{NO}_{3}^{-} \\
\left(\mathrm{mg} \mathrm{kg}^{-1} \mathrm{FW}\right)\end{array}$ \\
\hline \multicolumn{7}{|c|}{$\mathrm{GA}_{3}(\mathrm{M})$} \\
\hline & & $0.83^{z}$ & 3.1 & 29.7 & 59.6 & $2599.7 \mathrm{a}$ \\
\hline & & 0.84 & 3.1 & 27.9 & 57.4 & $2337.2 \mathrm{a}$ \\
\hline & & 0.93 & 3.1 & 29.5 & 56.9 & $1848.8 \mathrm{~b}$ \\
\hline \multicolumn{7}{|c|}{ Storage $\left(\mathrm{d}\right.$ at $\left.4{ }^{\circ} \mathrm{C}\right)$} \\
\hline & & & $2.8 \mathrm{~b}$ & 28.5 & 63.2 & 2374.8 \\
\hline & & $0.50 \mathrm{~b}$ & $3.2 \mathrm{ab}$ & 27.8 & 49.8 & 2265.6 \\
\hline & & $0.70 \mathrm{~b}$ & 3.0ab & 31.1 & 59.8 & 2410.0 \\
\hline & & $1.41 \mathrm{a}$ & $3.3 a$ & 28.8 & 59.0 & 1997.2 \\
\hline \multicolumn{7}{|c|}{$\mathrm{GA}_{3} \times$ Storage } \\
\hline 0 & 0 & & 2.9 & 30.7 & 78.5 & 2690.3 \\
\hline 0 & 10 & 0.40 & 3.3 & 28.5 & 52.5 & 2495.0 \\
\hline 0 & 14 & 0.52 & 2.9 & 29.8 & 52.5 & 2665.0 \\
\hline 0 & 21 & 1.59 & 3.2 & 29.8 & 55.0 & 2548.3 \\
\hline $10^{-8}$ & 0 & & 3.1 & 28.8 & 53.0 & 2328.8 \\
\hline $10^{-8}$ & 10 & 0.57 & 3.2 & 26.9 & 49.0 & 2376.7 \\
\hline $10^{-8}$ & 14 & 0.77 & 2.8 & 28.8 & 65.0 & 2640.0 \\
\hline $10^{-8}$ & 21 & 1.19 & 3.2 & 26.9 & 62.5 & 2003.3 \\
\hline $10^{-6}$ & 0 & & 2.5 & 25.9 & 58.0 & 2105.3 \\
\hline $10^{-6}$ & 10 & 0.53 & 3.1 & 27.9 & 48.0 & 1925.0 \\
\hline $10^{-6}$ & 14 & 0.82 & 3.3 & 34.6 & 62.0 & 1925.0 \\
\hline $10^{-6}$ & 21 & 1.45 & 3.4 & 29.8 & 59.5 & 1440.0 \\
\hline \multicolumn{2}{|c|}{$\mathrm{GA}_{3}$} & $\mathrm{~ns}^{\mathrm{x}}$ & ns & ns & ns & $* *$ \\
\hline \multicolumn{2}{|c|}{ Storage } & $* * *$ & * & ns & ns & ns \\
\hline \multicolumn{2}{|c|}{$\mathrm{GA}_{3} \times$ Storage } & ns & ns & ns & ns & ns \\
\hline
\end{tabular}

${ }^{\mathrm{z}}$ each value is the mean of three replicates. Values in a column followed by the same letter are not significantly different, according to LSD test. ${ }^{\mathrm{x}}$ significance (ns = not significant); ${ }^{*}$ significant at $p<0.05$; ${ }^{* *}$ significant at $p<0.01$; *** significant at $p<0.001$. ${ }^{y}$ Titratable acidity expressed as citric acid.

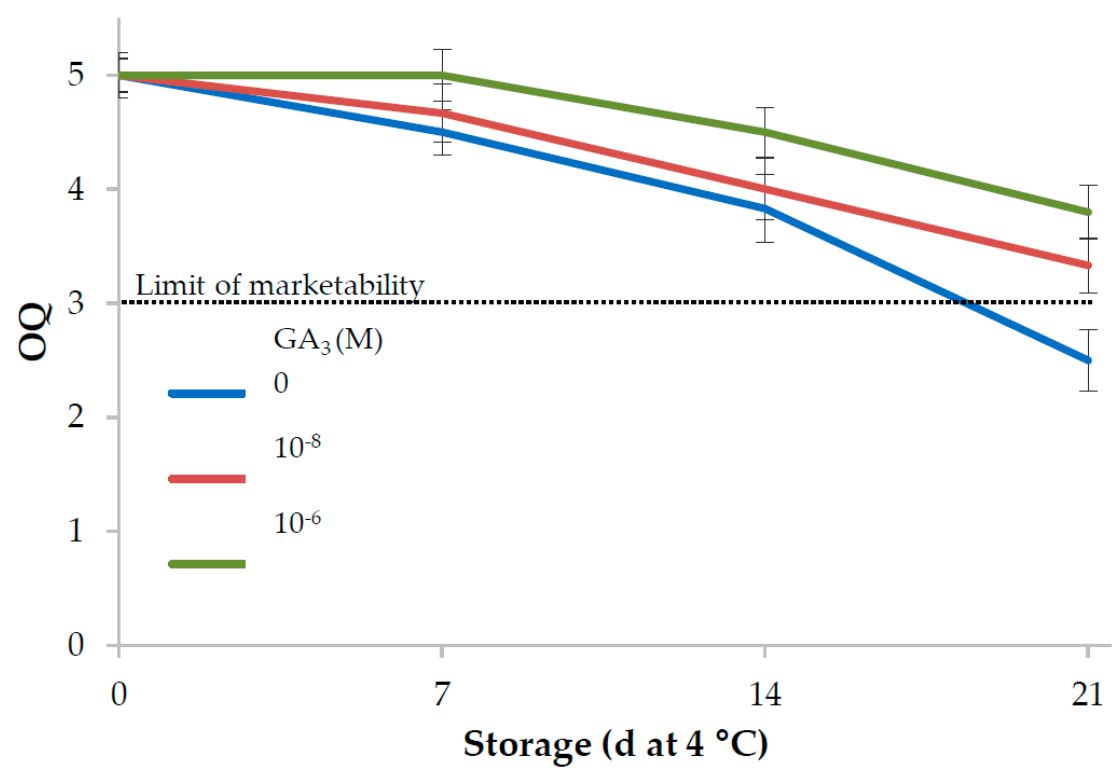

Figure 1. Influence of $\mathrm{GA}_{3}$ treatments and storage at $4{ }^{\circ} \mathrm{C}$ on overall quality of minimally processed lettuce (5: excellent or having a fresh appearance; 3 : average—limit of marketability; 1 : unmarketable). 
Table 3. Effect of $\mathrm{GA}_{3}$ and storage duration (d) on leaf appearance of minimally processed leaf lettuce.

\begin{tabular}{|c|c|c|c|c|c|c|c|}
\hline \multicolumn{2}{|c|}{ Treatments } & $\mathbf{L}^{*}$ & $a^{*}$ & $\mathbf{b}^{*}$ & Chroma & Hue & OQ \\
\hline \multicolumn{8}{|c|}{$\mathrm{GA}_{3}(\mathrm{M})$} \\
\hline & & $56.4^{\mathrm{z}}$ & -21.7 & $39.4 a$ & 44.4 & 118.9 & $4.0 \mathrm{~b}$ \\
\hline & & 55.6 & -21.5 & $38.9 \mathrm{ab}$ & 44.4 & 119.0 & $4.3 \mathrm{ab}$ \\
\hline & & 55.3 & -21.7 & $38.7 \mathrm{~b}$ & 45.0 & 119.2 & $4.6 \mathrm{a}$ \\
\hline \multicolumn{8}{|c|}{ Storage $\left(\mathrm{d}\right.$ at $\left.4{ }^{\circ} \mathrm{C}\right)$} \\
\hline & & 52.2 & $-21.8 \mathrm{ab}$ & $38.2 \mathrm{c}$ & $44.0 \mathrm{~b}$ & $119.8 \mathrm{a}$ & $5.0 \mathrm{a}$ \\
\hline & & 57.0 & $-22.0 \mathrm{a}$ & $39.4 \mathrm{bc}$ & $45.2 \mathrm{a}$ & $119.2 b$ & $4.7 \mathrm{a}$ \\
\hline & & 57.0 & $-21.5 b c$ & $38.8 \mathrm{ab}$ & $44.3 \mathrm{ab}$ & $119.0 \mathrm{~b}$ & $4.1 \mathrm{~b}$ \\
\hline & & 56.7 & $-21.3 c$ & $39.6 a$ & $45.0 \mathrm{a}$ & $118.2 \mathrm{c}$ & $3.2 \mathrm{c}$ \\
\hline \multicolumn{8}{|c|}{$\mathrm{GA}_{3} \times$ Storage } \\
\hline 0 & 0 & $54.8 \mathrm{a}$ & -21.7 & 39.0 & 44.1 & 119.1 & 5.0 \\
\hline 0 & 10 & $57.7 \mathrm{~b}$ & -22.1 & 39.6 & 45.1 & 119.1 & 4.5 \\
\hline 0 & 14 & $56.7 \mathrm{ab}$ & -21.6 & 39.0 & 43.7 & 119.1 & 3.8 \\
\hline 0 & 21 & $56.3 \mathrm{ab}$ & -21.4 & 40.0 & 44.8 & 118.2 & 2.5 \\
\hline $10^{-8}$ & 0 & $51.0 \mathrm{c}$ & -22.0 & 38.2 & 43.1 & 120.0 & 5.0 \\
\hline $10^{-8}$ & 10 & $56.7 \mathrm{ab}$ & -21.8 & 39.4 & 45.1 & 119.0 & 4.7 \\
\hline $10^{-8}$ & 14 & 57.1ab & -21.2 & 38.2 & 44.7 & 119.0 & 4.0 \\
\hline $10^{-8}$ & 21 & $57.6 \mathrm{a}$ & -21.1 & 39.6 & 44.8 & 118.1 & 3.3 \\
\hline $10^{-6}$ & 0 & $50.9 c$ & -21.7 & 37.2 & 44.7 & 120.3 & 5.0 \\
\hline $10^{-6}$ & 10 & $56.7 \mathrm{ab}$ & -22.1 & 39.3 & 45.4 & 119.3 & 5.0 \\
\hline $10^{-6}$ & 14 & $57.3 \mathrm{ab}$ & -21.5 & 39.1 & 44.6 & 118.9 & 4.5 \\
\hline $10^{-6}$ & 21 & $56.2 \mathrm{ab}$ & -21.3 & 39.4 & 45.4 & 118.4 & 3.8 \\
\hline \multicolumn{2}{|c|}{$\mathrm{GA}_{3}$} & $* x$ & ns & * & ns & ns & $* * *$ \\
\hline \multicolumn{2}{|c|}{ Storage } & $* * *$ & $* * *$ & $* * *$ & $* * *$ & $* * *$ & $* * *$ \\
\hline \multicolumn{2}{|c|}{$\mathrm{GA}_{3} \times$ Storage } & $* *$ & ns & ns & ns & ns & ns \\
\hline
\end{tabular}

${ }^{\mathrm{z}}$ each value is the mean of three replicates. Values in a column followed by the same letter are not significantly different, according to LSD test. ${ }^{\mathrm{x}}$ significance (ns = not significant); ${ }^{*}$ significant at $p<0.05 ;{ }^{* *}$ significant at $p<0.01$; *** significant at $p<0.001$. OQ: overall quality.

\subsection{Rocket}

The yield of rocket plants grown with $0 \mathrm{M} \mathrm{GA}_{3}$ in the MNS was $2.9 \mathrm{~kg} \mathrm{~m}^{-2}$. By adding GA 3 to the MNS, the yield of rocket plants increased, and reached the highest value with the highest $\mathrm{GA}_{3}$ concentration $\left(4.1 \mathrm{~kg} \mathrm{~m}^{-2} ;+41.4 \%\right)$ (Table 1$)$. The percentage processing yield of fresh-cut leaves was not influenced by the experimental treatments and was on average $71.1 \%$. Thus, the amount of minimally processed leaves produced was $2.0 \mathrm{~kg} \mathrm{~m}^{-2}$ and increased up to $2.9 \mathrm{~kg} \mathrm{~m}^{-2}$ with $10^{-6} \mathrm{M} \mathrm{GA}_{3}$ in the MNS (Table 1).

The weight loss of the control samples of rocket was $1.29 \mathrm{~g} 100 \mathrm{~g}^{-1} \mathrm{FW}$ and was significantly reduced by $\mathrm{GA}_{3}$ treatments ( $-37.7 \%$ on average). Weight loss also showed a positive correlation with storage time $\left(\mathrm{R}^{2}=0.990\right)$ as it increased linearly up to $1.29 \mathrm{~g} 100 \mathrm{~g}^{-1} \mathrm{FW}$ after $21 \mathrm{~d}$ of storage (Table 4$)$.

All the chemical parameters examined showed effects of storage time, but only the ascorbic acid and nitrate contents were affected by $\mathrm{GA}_{3}$ (Table 4). TSS and TA increased their values after $7 \mathrm{~d}$ of storage $\left(5.9^{\circ}\right.$ Brix and $52.5 \mathrm{mg} 100 \mathrm{~g}^{-1} \mathrm{FW}$ for day 7 and 14 , respectively) and dropped to the initial levels at the end of storage. The ascorbic acid content of the control samples was $220.5 \mathrm{mg}^{100 \mathrm{~g}^{-1}}$ FW and was positively influenced by the highest $\mathrm{GA}_{3}$ concentration $\left(10^{-6} \mathrm{M}\right)$ that raised it up to $257.5 \mathrm{mg} 100 \mathrm{~g}^{-1} \mathrm{FW}$. Soon after minimal processing, the ascorbic acid content of the samples was $204.0 \mathrm{mg} 100 \mathrm{~g} \mathrm{~g}^{-1} \mathrm{FW}$, while it increased significantly to $300.0 \mathrm{mg} 100 \mathrm{~g}^{-1} \mathrm{FW}$ after 2 weeks of storage (Table 4). 
Table 4. Effect of $\mathrm{GA}_{3}$ and storage duration (d) on weight loss, total soluble solids (TSS), titratable acidity (TA), ascorbic acid, and nitrates of minimally processed rocket.

\begin{tabular}{|c|c|c|c|c|c|c|}
\hline \multicolumn{2}{|c|}{ Treatments } & $\begin{array}{l}\text { Weight Loss } \\
\text { (g } 100 \mathrm{~g}^{-1} \text { FW) }\end{array}$ & $\begin{array}{c}\text { TSS } \\
\left({ }^{\circ} \text { Brix }\right)\end{array}$ & $\begin{array}{c}\text { TA }^{\mathrm{y}} \\
\left(\mathrm{mg} 100 \mathrm{~g}^{-1} \mathrm{FW}\right)\end{array}$ & $\begin{array}{l}\text { Ascorbic Acid } \\
\left(\mathrm{mg} 100 \mathrm{~g}^{-1} \mathrm{FW}\right)\end{array}$ & $\begin{array}{c}{\mathrm{N}-\mathrm{NO}_{3}^{-}}^{-} \\
\left(\mathrm{mg} \mathrm{kg}^{-1} \mathrm{FW}\right)\end{array}$ \\
\hline \multicolumn{7}{|c|}{$\mathrm{GA}_{3}(\mathrm{M})$} \\
\hline & & $1.29 \mathrm{a}^{\mathrm{z}}$ & 5.6 & 48.8 & $220.5 b$ & 2171.1a \\
\hline & & $0.82 \mathrm{~b}$ & 5.5 & 47.7 & $209.7 \mathrm{~b}$ & 2156.1a \\
\hline & & $0.79 b$ & 5.8 & 48.7 & $257.5 a$ & $1777.4 \mathrm{~b}$ \\
\hline \multicolumn{7}{|c|}{ Storage $\left(\mathrm{d}\right.$ at $\left.4{ }^{\circ} \mathrm{C}\right)$} \\
\hline & & & $5.5 \mathrm{bc}$ & $45.3 \mathrm{~b}$ & $204.0 \mathrm{~b}$ & $2383.2 \mathrm{a}$ \\
\hline & & $0.63 b$ & $6.1 \mathrm{a}$ & $51.7 \mathrm{a}$ & $158.3 b$ & 2044.9ab \\
\hline & & $0.98 \mathrm{ab}$ & $5.7 \mathrm{ab}$ & $53.4 \mathrm{a}$ & $300.0 \mathrm{a}$ & 1919.9ab \\
\hline & & $1.29 a$ & $5.1 \mathrm{c}$ & $43.3 \mathrm{~b}$ & $254.7 \mathrm{a}$ & $1791.6 b$ \\
\hline \multicolumn{7}{|c|}{$\mathrm{GA}_{3} \times$ Storage } \\
\hline 0 & 0 & & 5.8 & 46.1 & 173.0 & 2714.9 \\
\hline 0 & 10 & 0.66 & 6.2 & 48.7 & 144.0 & 2079.9 \\
\hline 0 & 14 & 1.54 & 5.3 & 55.1 & 296.0 & 1939.9 \\
\hline 0 & 21 & 1.66 & 5.1 & 45.5 & 269.0 & 1949.9 \\
\hline $10^{-8}$ & 0 & & 5.2 & 44.8 & 221.0 & 2364.9 \\
\hline $10^{-8}$ & 10 & 0.63 & 6.0 & 51.2 & 128.0 & 2224.9 \\
\hline $10^{-8}$ & 14 & 0.71 & 5.4 & 53.8 & 282.0 & 2199.9 \\
\hline $10^{-8}$ & 21 & 1.11 & 5.3 & 41.0 & 208.0 & 1834.9 \\
\hline $10^{-6}$ & 0 & & 5.4 & 44.8 & 218.0 & 2069.9 \\
\hline $10^{-6}$ & 10 & 0.60 & 6.2 & 55.1 & 203.0 & 1829.9 \\
\hline $10^{-6}$ & 14 & 0.68 & 6.5 & 51.2 & 322.0 & 1619.9 \\
\hline $10^{-6}$ & 21 & 1.09 & 5.0 & 43.5 & 287.0 & 1589.9 \\
\hline \multicolumn{2}{|c|}{$\mathrm{GA}_{3}$} & $* * \mathrm{x}$ & ns & ns & $* *$ & * \\
\hline \multicolumn{2}{|c|}{ Storage } & $* * *$ & $* * *$ & $* * *$ & $* * *$ & * \\
\hline \multicolumn{2}{|c|}{$\mathrm{GA}_{3} \times$ Storage } & ns & ns & ns & ns & ns \\
\hline
\end{tabular}

${ }^{\mathrm{z}}$ each value is the mean of three replicates. Values in a column followed by the same letter are not significantly different, according to LSD test. ${ }^{\mathrm{x}}$ significance (ns = not significant); ${ }^{*}$ significant at $p<0.05$; ${ }^{* *}$ significant at $p<0.01$; *** significant at $p<0.001$. ${ }^{\mathrm{y}}$ Titratable acidity expressed as citric acid.

At the beginning of the storage period, the nitrate content of rocket leaves ranged between $2714.9 \mathrm{mg} \mathrm{kg}^{-1} \mathrm{FW}$ in the control samples and $2069.9 \mathrm{mg} \mathrm{kg}^{-1} \mathrm{FW}$ in the $10^{-6} \mathrm{M} \mathrm{GA}_{3}$ samples. This treatment caused a significant reduction $(-17.9 \%)$ of the average nitrate content of rocket leaves throughout the storage period compared with the others $\left(2163.6 \mathrm{mg} \mathrm{kg}^{-1} \mathrm{FW}\right.$ on average). A significant decrease was also observed during storage; at the end of the experiment the nitrate content of rocket leaves was $24.8 \%$ lower than the initial value (2383.2 $\mathrm{mg} \mathrm{kg}^{-1} \mathrm{FW}$ ) (Table 4).

Rocket leaves showed color changes due to $\mathrm{GA}_{3}$ and storage. $\mathrm{GA}_{3}$ treatments, especially at the highest concentration, caused a darker color (lower $\mathrm{L}^{*}$ values), with higher $\mathrm{a}^{*}$ and lower $\mathrm{b}^{*}$ values than control leaves, resulting in a less vivid color (lower chroma) with a slightly higher hue angle (Table 5). During storage, rocket leaf color tended to be lighter (increased $L^{*}$ values), with lower $\mathrm{a}^{*}$ and higher $\mathrm{b}^{*}$ values, showing an increase of chroma and a reduction of the hue angle that indicated a yellower saturated color (Table 5).

The overall quality (OQ) estimated by an informal panel was not significantly influenced by $\mathrm{GA}_{3}$ treatments, whereas OQ slowly but significantly decreased during the storage period (Table 5). The scores of OQ were above 4 until the 14th day of storage in all the samples (4.3 on average), but were near the limit of marketability in the $\mathrm{GA}_{3}$ samples (3.1 on average) and dropped below this threshold in the control samples at the end of storage (Figure 2). 
Table 5. Effect of $\mathrm{GA}_{3}$ and storage duration (d) on leaf appearance of minimally processed rocket.

\begin{tabular}{|c|c|c|c|c|c|c|c|}
\hline \multicolumn{2}{|c|}{ Treatments } & $\mathbf{L}^{*}$ & $a^{*}$ & $\mathbf{b}^{*}$ & Chroma & Hue & OQ \\
\hline \multicolumn{8}{|c|}{$\mathrm{GA}_{3}(\mathrm{M})$} \\
\hline & & $45.2 \mathrm{a}^{\mathrm{z}}$ & $-19.5 b$ & $26.5 a$ & $32.9 a$ & 126.6 & 4.0 \\
\hline & & $44.4 \mathrm{~b}$ & $-19.1 b$ & $25.7 \mathrm{ab}$ & $32.0 \mathrm{ab}$ & 126.9 & 4.1 \\
\hline & & $44.4 \mathrm{~b}$ & $-18.6 \mathrm{a}$ & $24.8 \mathrm{~b}$ & $31.0 \mathrm{~b}$ & 127.1 & 4.3 \\
\hline \multicolumn{8}{|c|}{ Storage $\left(\mathrm{d}\right.$ at $\left.4{ }^{\circ} \mathrm{C}\right)$} \\
\hline & & $43.7 c$ & $-19.0 \mathrm{ab}$ & $25.2 \mathrm{~b}$ & $31.6 b$ & $127.2 \mathrm{a}$ & $5.0 \mathrm{a}$ \\
\hline & & $44.5 \mathrm{bc}$ & $-18.7 \mathrm{a}$ & $24.9 \mathrm{~b}$ & $31.2 b$ & $127.1 \mathrm{a}$ & $4.3 b$ \\
\hline & & $45.0 \mathrm{ab}$ & $-19.4 b$ & $25.8 \mathrm{ab}$ & $32.3 \mathrm{ab}$ & $127.2 \mathrm{a}$ & $4.3 b$ \\
\hline & & $45.5 a$ & $-19.2 b$ & $26.7 \mathrm{a}$ & $33.0 \mathrm{a}$ & $126.0 \mathrm{~b}$ & $2.9 c$ \\
\hline \multicolumn{8}{|c|}{$\mathrm{GA}_{3} \times$ Storage } \\
\hline 0 & 0 & 44.7 & -19.4 & 26.2 & 32.6 & 126.8 & 5.0 \\
\hline 0 & 10 & 45.5 & -19.3 & 26.1 & 32.4 & 126.6 & 4.3 \\
\hline 0 & 14 & 45.2 & -19.9 & 26.5 & 33.1 & 127.1 & 4.2 \\
\hline 0 & 21 & 45.5 & -19.6 & 27.2 & 33.6 & 125.9 & 2.7 \\
\hline $10^{-8}$ & 0 & 43.2 & -19.0 & 25.1 & 31.5 & 127.4 & 5.0 \\
\hline $10^{-8}$ & 10 & 44.0 & -18.9 & 25.1 & 31.4 & 127.1 & 4.2 \\
\hline $10^{-8}$ & 14 & 44.8 & -19.5 & 25.6 & 32.2 & 127.4 & 4.2 \\
\hline $10^{-8}$ & 21 & 45.7 & -19.3 & 26.9 & 33.1 & 125.9 & 3.0 \\
\hline $10^{-6}$ & 0 & 43.1 & -18.6 & 24.3 & 30.6 & 127.5 & 5.0 \\
\hline $10^{-6}$ & 10 & 44.0 & -18.0 & 23.5 & 29.6 & 127.6 & 4.5 \\
\hline $10^{-6}$ & 14 & 45.0 & -19.0 & 25.3 & 31.6 & 127.1 & 4.5 \\
\hline $10^{-6}$ & 21 & 45.3 & -18.8 & 26.1 & 32.2 & 126.1 & 3.2 \\
\hline \multicolumn{2}{|c|}{$\mathrm{GA}_{3}$} & $* x$ & $* * *$ & $* * *$ & $* * *$ & ns & ns \\
\hline \multicolumn{2}{|c|}{ Storage } & $* * *$ & $* * *$ & $* *$ & $* *$ & $* * *$ & $* * *$ \\
\hline \multicolumn{2}{|c|}{$\mathrm{GA}_{3} \times$ Storage } & ns & ns & ns & ns & ns & ns \\
\hline
\end{tabular}

${ }^{\mathrm{z}}$ each value is the mean of three replicates. Values in a column followed by the same letter are not significantly different, according to LSD test $p \leq 0.05 .{ }^{\mathrm{x}}$ significance (ns = not significant); ${ }^{*}$ significant at $p<0.05 ;{ }^{* *}$ significant at $p<0.01 ;{ }^{* * *}$ significant at $p<0.001$.

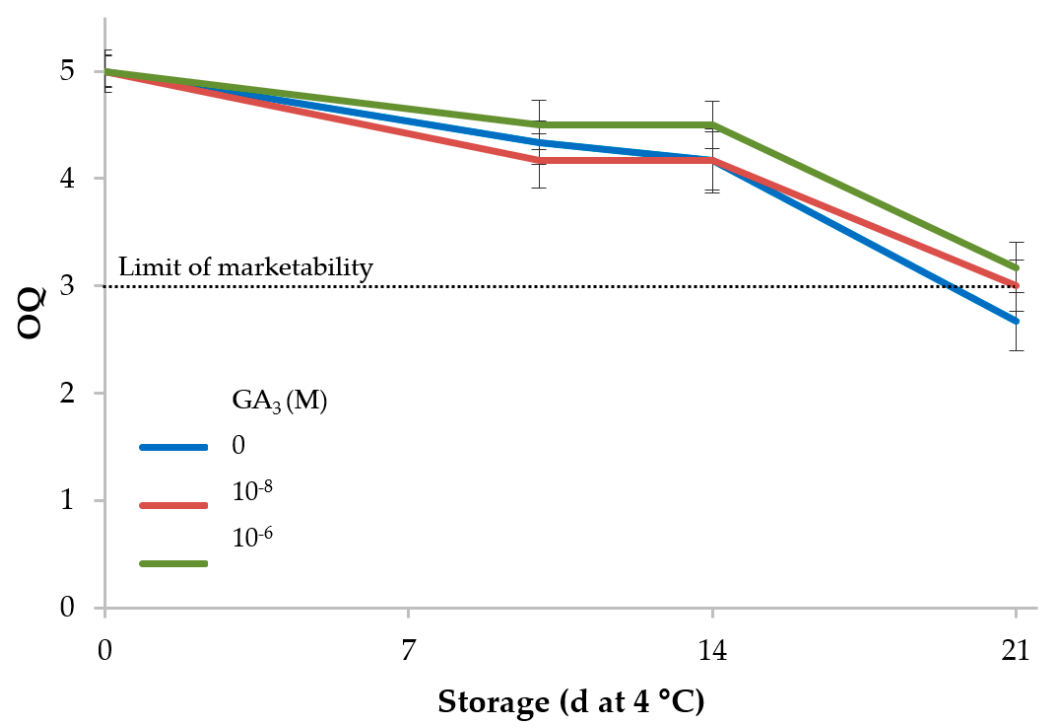

Figure 2. Influence of $\mathrm{GA}_{3}$ treatments and storage at $4{ }^{\circ} \mathrm{C}$ on overall quality of minimally processed rocket (5: excellent or having a fresh appearance; 3: average-limit of marketability; 1 : unmarketable).

\subsection{Principal Components Analysis}

To obtain a broad overview of the morphological, physiological and biochemical, parameters characterizing minimally processed leaf lettuce and rocket under different $\mathrm{GA}_{3} \times$ storage treatments, a Principal Component Analysis (PCA) was carried out. The results of the principal components analysis 
showed two principal components (PCs) with eigenvalues higher than 1.00 (Table 5), accounting for $69.42 \%$ and $19.35 \%$ of the total variance, respectively. This indicated that the initial 11 variables could be expressed as a linear combination of two PCs, explaining $88.77 \%$ of the total variance. PC1 was positively related to TSS, TA, ascorbic acid content, $\mathrm{a}^{*}$, and hue and was negatively related to $\mathrm{L}^{*}, \mathrm{~b}^{*}$, and chroma. Moreover, PC2 was positively related to OQ and was negatively related to weight loss (Table 6).

Table 6. Correlation of variables to the factors of the principal components analysis (PCA) based on factor loadings.

\begin{tabular}{ccc}
\hline Variables & PC1 & PC2 \\
\hline Weight loss & 0.071 & $\mathbf{0 . 9 6 8}$ \\
TSS & $\mathbf{0 . 9 6 5}$ & 0.021 \\
TA & $\mathbf{0 . 9 5 8}$ & 0.006 \\
Ascorbic acid & $\mathbf{0 . 9 1 0}$ & -0.144 \\
$\mathrm{~N}^{-N^{-}}$ & -0.413 & 0.557 \\
$\mathrm{~L}^{*}$ & $\mathbf{- 0 . 9 5 5}$ & -0.174 \\
$\mathrm{a}^{*}$ & $\mathbf{0 . 9 6 4}$ & -0.011 \\
$\mathrm{~b}^{*}$ & $\mathbf{- 0 . 9 9 2}$ & -0.090 \\
Chroma $_{\text {Hue }}$ & $\mathbf{- 0 . 9 9 1}$ & -0.080 \\
OQ & $\mathbf{0 . 9 8 6}$ & 0.129 \\
\hline
\end{tabular}

Values in bold within the same factor indicate the variable with the largest correlation.

The initial 11 variables projected on the plane of the two PCs clearly confirm such a relationship, as shown in the plot of loadings (Figure 3a). The discrimination of the various combinations of preharvest $\mathrm{GA}_{3}$ treatments $\times$ storage time of minimally processed leaf lettuce and rocket can be visualized in the plot of scores (Figure $3 b$ ), where two clusters can be clearly distinguished. The scores of minimally processed lettuce were positioned in the negative side of $\mathrm{PC} 1$ and clearly separated from those of rocket, located in the positive part of PC1. Each cluster could be split into smaller subclusters: 3 subclusters for lettuce and 4 subclusters for rocket. The samples of lettuce soon after processing were clustered together in the upper left quadrant; a second subcluster clumped together all the scores of day 7 and 14 , with a decreasing trend for PC2 values, that were negative only for lettuce samples treated with $10^{-8} \mathrm{M}$ and $10^{-6} \mathrm{M} \mathrm{GA}_{3}$ after $14 \mathrm{~d}$ of storage; the third subcluster grouped together in the lower left quadrant all the lettuce samples at the end of storage $(21 \mathrm{~d})$. The scores of minimally processed rocket showed more influence from $\mathrm{GA}_{3}$ treatments. At day 0 , the samples of rocket were clumped in a subcluster located in the upper right quadrant, but with an increasing trend of PC1 and a decreasing trend of PC2 as $\mathrm{GA}_{3}$ level increased; a second cluster grouped together all the $\mathrm{GA}_{3}$ treatments stored for $7 \mathrm{~d}$ and the samples treated with $10^{-8}$ and $10^{-6} \mathrm{M} \mathrm{GA}_{3}$ stored for $14 \mathrm{~d}$, with both samples treated with $10^{-6} \mathrm{M}$ $\mathrm{GA}_{3}$ that showed higher PC1 values; the samples of rocket treated with $10^{-8}$ and $10^{-6} \mathrm{M} \mathrm{GA}_{3}$ stored for $21 \mathrm{~d}$ and those of the controls stored for $14 \mathrm{~d}$ could be assigned to the third subcluster located in the lower right quadrant, where a fourth subcluster could be also detected. This last subcluster included only the nontreated minimally processed rocket stored for $21 \mathrm{~d}$, which had the lowest PC2 value. Combining the information from the plots, it can be concluded that $\mathrm{GA}_{3}$ doses influenced leaf lettuce and rocket in different ways (Figure $3 a, b$ ). Lettuce was related with all the parameters negatively related to $\mathrm{PC} 1$, whereas rocket was related with all the parameters positively related to PC1. Storage time was negatively related to PC2 (weight loss and OQ). During cold storage, the samples treated with $10^{-6} \mathrm{M} \mathrm{GA}_{3}$ showed, generally, higher PC1 values than the others. 


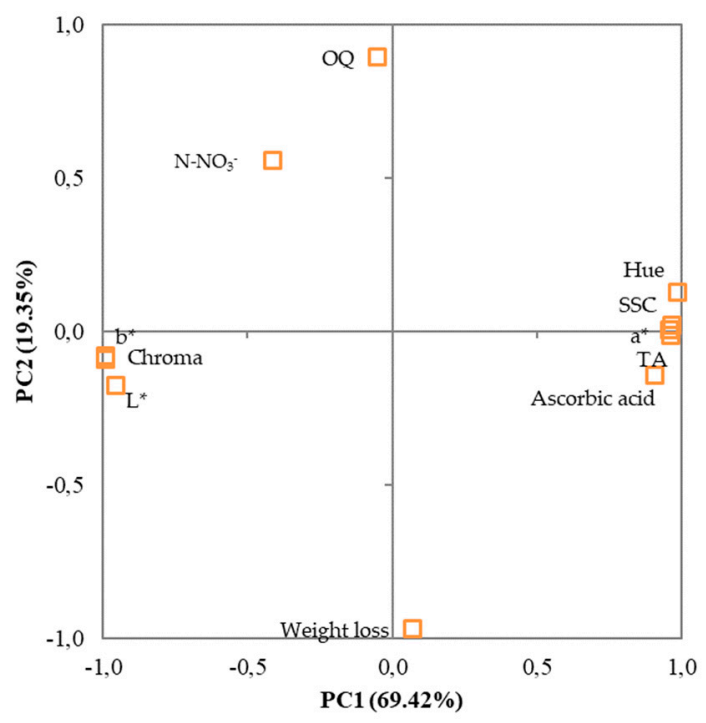

(a)

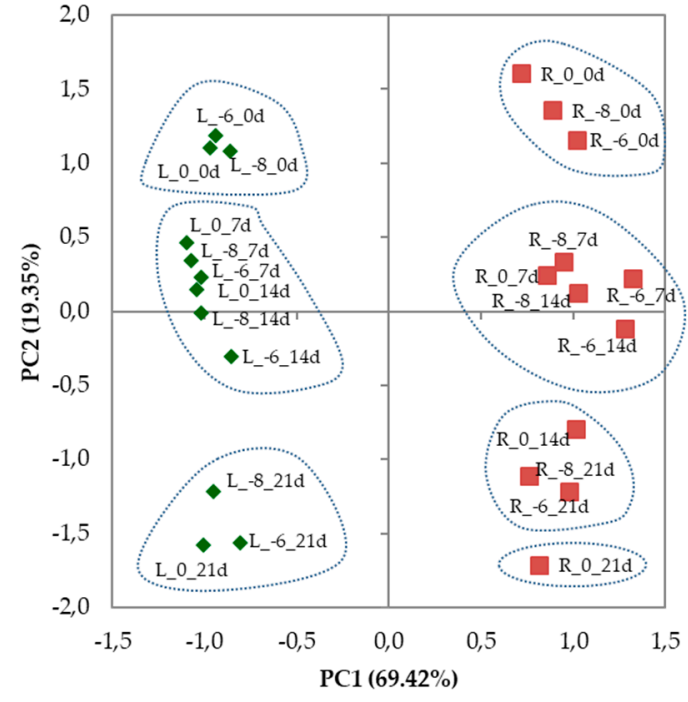

(b)

Figure 3. Plot of (a) loadings (quality characteristics of minimally processed leaf lettuce and rocket during $21 \mathrm{~d}$ of storage at $4{ }^{\circ} \mathrm{C}$ ) and (b) scores (trials) formed by the two principal components from the Principal Component Analysis. L_0, L_-8, and L_-6: lettuce (green rhombuses) cultivated in nutrient solutions with $0,10^{-8}$ and $10^{-6} \mathrm{M} \mathrm{GA}_{3}$, respectively; $\mathrm{R} \_0, \mathrm{R}_{-}-8$, and $\mathrm{R}_{-}-6$ : rocket (red squares) cultivated in nutrient solutions with $0,10^{-8}$ and $10^{-6} \mathrm{M} \mathrm{GA}_{3}$, respectively;_0d,_7d,_14d, and_21d: days of storage at $4{ }^{\circ} \mathrm{C}$.

\section{Discussion}

Plant growth regulators (PGRs) have been used in agriculture since their discovery to control plant processes (germination, vegetative growth, reproductive development, maturity, senescence, and postharvest preservation) [17]. Gibberellins are PGRs associated with many plant physiological activities [47] that have been used commercially to improve morphological and phenotypic characteristics, and earliness and yield of many vegetable and ornamental crops [48]. Gibberellins have also been tested as postharvest treatments, with the aim of preserving stored products from decay and biotic or abiotic stress. The doses of $\mathrm{GA}_{3}$ applied to plants may vary greatly. Many experiments have been carried out to study the effects of spraying exogenous $\mathrm{GA}_{3}$ at very low concentrations on various crops $[18,25,36,37,40,49-51]$, showing that $\mathrm{GA}_{3}$ relative concentrations and responses may differ according to species and their growth stages [34]. This indicates the need to evaluate the effects of applying different $\mathrm{GA}_{3}$ doses to different vegetables crop during both growth and postharvest. In fact, many crop practices may exert their effects on products also after harvesting. At harvest, vegetables are removed from the parent plant and so they lose the normal supply of water, nutrients, and organic molecules including hormones, which may be supplied by translocation from other parts of the plant during growth. Nevertheless, endogenous hormones go on functioning and controlling physiological processes of vegetables even during storage [52]. This suggested an opportunity to control and slow postharvest changes in fruits, vegetables, and flowers by exogenous application of phytohormones. Postharvest $\mathrm{GA}_{3}$ treatments have been used in preserving stored products because they were shown to be efficient, nontoxic, biodegradable, and with no residual [30-33]. However, little information is available concerning the role of preharvest and postharvest $\mathrm{GA}_{3}$ treatments during cold storage of minimally processed leafy vegetables. Thus, we aimed to determine if the preharvest application of $\mathrm{GA}_{3}$ through the MNS of a hydroponic floating system could affect quality characteristics of minimally processed leaf lettuce and rocket at harvest and during cold storage.

The modification that plant growth regulators can cause on plant phenotype, growth, and development by altering the hormonal content and their balance may play a role in modifying crop 
yield [53-57]. Leaf lettuce and rocket yield were positively affected by exogenous $\mathrm{GA}_{3}$ supplied through the MNS at $10^{-6} \mathrm{M} \mathrm{GA}_{3}$ [42]. The growth-promoting effect of $\mathrm{GA}_{3}$ resulted in a significantly higher yield of both raw and minimally processed leafy vegetables. $\mathrm{GA}_{3}$-treated plants showed an enhanced activity of enzymes that have a role in photosynthetic processes [58,59]; thus, $\mathrm{GA}_{3}$ may indirectly increase the photosynthetic rate $[52,54,58,60]$, leading to greater dry mass accumulation and higher yield.

Weight loss occurring during storage is one of the main issues that may negatively influence the appearance and quality of minimally processed leafy vegetables. It could be directly linked with water loss, but also with respiration that degrades carbohydrate reserves [61,62]. This parameter may be used as an index of the impact of abiotic stress and storage conditions on fresh cut products $[63,64]$. Minimally processed vegetables are usually packed in sealed plastic bags that have low permeability to water vapor; this characteristic determines the quick rise in relative humidity (RH) to a very high level (almost 100\% RH) inside the bags [65-68], so dehydration is not a main issue, as we found for the leafy vegetables tested in this work. The weight losses of minimally processed lettuce and rocket leaves were similar on average at the end of storage; $\mathrm{GA}_{3}$ preharvest application was effective in reducing weight loss of rocket leaves but had no effect on lettuce leaves. Water loss is mainly due to the reduction of the resistance of outer periderm or cuticle to transpiration, caused by processing or by leaf tissue deterioration [69]. $\mathrm{GA}_{3}$ may influence cuticle thickness and epidermal cell dimension, but to different extents based on species and cultivar [70], as we found for leaf lettuce and rocket, and may also have a role in decreasing the activity of cell wall-hydrolyzing enzymes [71]. Even though plant cell walls are permeable to water, the higher integrity of this structure might increase resistance to water flux [72]. Thus, the lower weight loss observed in the $\mathrm{GA}_{3}$-treated rocket leaves might be attributed to the maintenance of tissue integrity due to lower activity of enzymes responsible for decomposing cellular structure [71].

Total soluble solids and titratable acidity were not affected by $\mathrm{GA}_{3}$ preharvest supply in both lettuce and rocket but showed variations during cold storage. Minimally processed leaves may increase their respiration activity and ethylene production during storage, and these metabolic variations could influence the amount of complex and soluble sugars and organic acids. Thus, the increase of TSS and total acidity found after 7 and $14 \mathrm{~d}$ of storage could be an indirect indication of the increasing metabolic activity of leaf lettuce and rocket leaves during cold storage. Similar increases of total acidity have been found during cold storage of minimally processed cauliflower [68,73], fresh-cut red chicory [65], and escarole [66]. Soluble sugars are transformed to organic acids and to other simple carbon compounds, thus determining the contemporary increase of titratable acidity during storage in both leafy vegetables. Lers et al. [74] found that preharvest $\mathrm{GA}_{3}$ treatments were effective in reducing the respiration rate of parsley leaves stored for $8 \mathrm{~d}$ at $25^{\circ} \mathrm{C}$, while in our experiment we did not find a modification of metabolites (soluble sugars or total acidity) that could have confirmed the effect of $\mathrm{GA}_{3}$ on respiration rate. This was probably due to the low temperature and to the atmosphere inside the sealed bags that was effective in slowing the respiration process [65,75].

Among the organic acids found in vegetables, ascorbic acid (vitamin C) is an important element of nutritional quality, as its consumption has been related to a lower incidence of several chronic diseases including cardiovascular disease and cancer [76]. Producing vegetables with a high vitamin $\mathrm{C}$ content and maintaining the level of vitamin $\mathrm{C}$ during postharvest storage time is essential for enhancing their nutritional value. Leaf lettuce had a lower ascorbic acid content than rocket and was not influenced by $\mathrm{GA}_{3}$ treatment or cold storage. Even if ascorbic acid is a very labile compound that can be quickly degraded during postharvest storage of perishable foods, several studies have shown that its losses can be strongly limited or that it can even increase in packed cold-stored vegetables [67,77-80]. In fact, in our work, the content of ascorbic acid of rocket was positively affected by cold storage. Furthermore, growing rocket with $10^{-6} \mathrm{M} \mathrm{GA}_{3}$ in the MNS resulted in a higher content of ascorbic acid in rocket leaves at harvest and during cold storage. A similar effect on vitamin $\mathrm{C}$ content was found by El-Hamahmy et al. [81] on sugar snap peas after postharvest treatment with $\mathrm{GA}_{3}$ and during 
cold storage. The different response of leaf lettuce and rocket as regards ascorbic acid content could be related to differences in metabolic processes between the tested species. A relationship between the ascorbic acid content of leaves and nitrogen availability has been found in some fruits and vegetables, but this relationship may vary depending on many factors (e.g., genus, climate, etc.) [82,83]. Leafy vegetables need sufficient $\mathrm{N}$ supply to maintain ascorbic acid synthesis $[67,84]$. $\mathrm{GA}_{3}$ treatments can affect nitrogen metabolism and nitrogen redistribution to different plant organs and to different biochemical processes [42], thus, likely influencing ascorbic acid production.

The differing effect of $\mathrm{GA}_{3}$ on leaf lettuce and rocket was also found for their nitrate content. Nitrate accumulation in leafy vegetables can negatively affect human health and determine a decrease of nutritional quality or even the loss of marketability [85]. Minimally processed lettuce leaves showed an average initial nitrate content of $2448.3 \mathrm{mg} \mathrm{kg}^{-1} \mathrm{FW}$ that decreased during cold storage in $\mathrm{GA}_{3}$-treated leaves, while it remained constant in control leaves. Rocket leaves also exhibited a decrease of nitrate content during storage, but irrespective of $\mathrm{GA}_{3}$ treatments which, in turn, significantly affected initial nitrate accumulation, with a lower value with $10^{-6} \mathrm{M} \mathrm{GA}_{3}$ treatment. Gibberellic acid affects nitrogen metabolism and nitrogen redistribution in plants and has a positive effect on nitrate reductase activity $[58,86]$. Thus, $\mathrm{GA}_{3}$ treatments, above all $10^{-6} \mathrm{M} \mathrm{GA}_{3}$, might have influenced nitrate reductase, but in different ways in the tested leafy vegetables. The increased activity of this enzyme could have caused a reduction of nitrate accumulation in rocket during plant growth, while leaf lettuce plants may not have reduced the nitrate content during growth, for a more efficient translocation from roots to leaves and, when leaves were detached and deprived of nitrate supply, could have finally showed the higher nitrate reductase efficiency, promoted by $\mathrm{GA}_{3}$ treatment.

The quality of vegetable products, and those minimally processed above all, is strongly characterized by appearance and color. These characteristics can impact food choice and acceptability and may also influence the consumer's perception of sensory quality. Color modifications may be triggered by preharvest $[42,67,87]$ or postharvest $[65,66,68,88]$ factors. Color alterations that may occur in leafy vegetables are mainly related to browning and yellowing (chlorophyll degradation) and could determine marketability loss before physical, chemical, and microbiological alterations are perceivable [67]. During storage, color modifications were noted in lettuce and rocket at different extents for each color parameter. The effect of preharvest $\mathrm{GA}_{3}$ treatment was more significant for rocket than for lettuce. Nonetheless, at the end of the cold storage period, $\mathrm{GA}_{3}$-treated leaves of both leafy vegetables showed a higher hue angle that corresponds to a greener color and consequently to a higher chlorophyll content $[89,90]$. Preharvest [74] or postharvest $[30,91] \mathrm{GA}_{3}$ treatments have been effective in retarding various senescence processes (e.g., chlorophyll and protein loss and amino acid accumulation) in other leafy vegetables. The degradation of chlorophyll in detached leaves is attributed to the lack of sufficient endogenous hormones, which cease on excision of the leaves from the plant [82,92]. The inhibitory role of GAs in chlorophyll degradation has been confirmed in some other plant species [81,93-96].

Color retention during cold storage influences quality perception of the minimally processed leafy vegetable tested. Even small variations of color components can result in significant changes of color that can be noted by the human eye, as confirmed by the panel that assessed the overall quality. Scores for lettuce $O Q$ decreased during storage, with significantly higher values than the controls at the end of storage, following $10^{-6} \mathrm{M} \mathrm{GA}_{3}$ treatment. Cold storage in sealed plastic bags was effective in retarding alteration in appearance for at least two weeks $[65,66,68,73,75,97]$. Moreover, the slowed senescence of $\mathrm{GA}_{3}$-treated samples maintained an overall visual quality over the threshold of marketability in both lettuce and rocket for up to $21 \mathrm{~d}$ of cold storage.

As seen above, minimally processed leaf lettuce and rocket were in some cases differently affected by $\mathrm{GA}_{3}$ preharvest treatments. This difference is clearly shown by the Principal Component Analysis that summarize the different responses of the two leafy vegetables to preharvest treatments. Postharvest responses to preharvest $\mathrm{GA}_{3}$ treatments were species-specific and dose-dependent, thus confirming that hormone requirement, relative concentrations, and responses may vary for different species [34]. 


\section{Conclusions}

Adding $10^{-6} \mathrm{M} \mathrm{GA}_{3}$ to the nutrient solution of a hydroponic floating system resulted in a positive effect on the yield of leaf lettuce and rocket plants and on the amount of minimally processed leaves produced. Preharvest $\mathrm{GA}_{3}$ treatments also had positive effects on retarding senescence and enhancing shelf-life of minimally processed lettuce and rocket, but the degree of the effects was species-dependent.

Author Contributions: Conceptualization, A.M. (Alessandro Miceli), F.V. and A.M. (Alessandra Moncada); Data curation, A.M. (Alessandro Miceli), F.V. and A.M. (Alessandra Moncada); Formal analysis, A.M. (Alessandro Miceli); Funding acquisition, F.D.'A.; Investigation, A.M. (Alessandro Miceli), F.V., L.S. and A.M. (Alessandra Moncada); Methodology, A.M. (Alessandro Miceli); Writing-original draft, A.M. (Alessandro Miceli) and F.V.; Writing-review \& editing, A.M. (Alessandro Miceli) and A.M. (Alessandra Moncada).

Funding: This research received no external funding.

Conflicts of Interest: The authors declare no conflict of interest.

\section{References}

1. Chakraborty, I.; Chattopadhyay, A. Pre- and Post-Harvest Losses in Vegetables. In Advances in Postharvest Technologies of Vegetable Crops; CRC Press: Boca Raton, FL, USA, 2018; pp. 25-87.

2. Lynch, M.F.; Tauxe, R.V.; Hedberg, C.W. The growing burden of foodborne outbreaks due to contaminated fresh produce: Risks and opportunities. Epidemiol. Infect. 2009, 137, 307-315. [CrossRef] [PubMed]

3. Settanni, L.; Miceli, A.; Francesca, N.; Cruciata, M.; Moschetti, G. Microbiological investigation of Raphanus sativus L. grown hydroponically in nutrient solutions contaminated with spoilage and pathogenic bacteria. Int. J. Food Microbiol. 2013, 160, 344-352. [CrossRef] [PubMed]

4. Tomasi, N.; Pinton, R.; Costa, L.D.; Cortella, G.; Terzano, R.; Mimmo, T.; Scampicchio, M.; Cesco, S. New 'solutions' for floating cultivation system of ready-to-eat salad: A review. Trends Food Sci. Technol. 2015, 46, 267-276. [CrossRef]

5. Khan, I.; Tango, C.N.; Miskeen, S.; Lee, B.H.; Oh, D.H. Hurdle technology: A novel approach for enhanced food quality and safety-A review. Food Control 2017, 73, 1426-1444. [CrossRef]

6. Soerjomataram, I.; Oomen, D.; Lemmens, V.; Oenema, A.; Benetou, V.; Trichopoulou, A.; Coebergh, J.W.; Barendregt, J.; De Vries, E. Increased consumption of fruit and vegetables and future cancer incidence in selected European countries. Eur. J. Cancer 2010, 46, 2563-2580. [CrossRef]

7. Karam, M.C.; Petit, J.; Zimmer, D.; Djantou, E.B.; Scher, J. Effects of drying and grinding in production of fruit and vegetable powders: A review. J. Food Eng. 2016, 188, 32-49. [CrossRef]

8. Francesca, N.; Guarcello, R.; Craparo, V.; Moschetti, G.; Settanni, L.; Gaglio, R. Microbial Ecology of Retail Ready-to-Eat Escarole and Red Chicory Sold in Palermo City, Italy. J. Food Qual. Hazards Control 2019, 6, 45-52. [CrossRef]

9. Miceli, A.; Settanni, L. Influence of agronomic practices and pre-harvest conditions on the attachment and development of Listeria monocytogenes in vegetables. Ann. Microbiol. 2019, 69, 185-199. [CrossRef]

10. Putnik, P.; Bursać Kovačević, D.; Herceg, K.; Roohinejad, S.; Greiner, R.; Bekhit, A.E.D.A.; Levaj, B. Modelling the shelf-life of minimally-processed fresh-cut apples packaged in a modified atmosphere using food quality parameters. Food Control 2011, 81, 55-64. [CrossRef]

11. Mir, S.A.; Shah, M.A.; Mir, M.M.; Dar, B.; Greiner, R.; Roohinejad, S. Microbiological contamination of ready-to-eat vegetable salads in developing countries and potential solutions in the supply chain to control microbial pathogens. Food Control 2018, 85, 235-244. [CrossRef]

12. Foley, J.A.; Ramankutty, N.; Brauman, K.A.; Cassidy, E.S.; Gerber, J.S.; Johnston, M.; Mueller, N.D.; O'Connell, C.; Ray, D.K.; West, P.C.; et al. Solutions for a cultivated planet. Nature 2011, 478, 337. [CrossRef] [PubMed]

13. Kummu, M.; De Moel, H.; Porkka, M.; Siebert, S.; Varis, O.; Ward, P. Lost food, wasted resources: Global food supply chain losses and their impacts on freshwater, cropland, and fertiliser use. Sci. Total Environ. 2012, 438, 477-489. [CrossRef] [PubMed]

14. Davis, K.F.; D'Odorico, P.; Rulli, M.C. Moderating diets to feed the future. Earth's Future 2014, 2, 559-565. [CrossRef] 
15. Davis, K.F.; Gephart, J.A.; Emery, K.A.; Leach, A.M.; Galloway, J.N.; D'Odorico, P. Meeting future food demand with current agricultural resources. Glob. Environ. Chang. 2016, 39, 125-132. [CrossRef]

16. Mueller, N.D.; Gerber, J.S.; Johnston, M.; Ray, D.K.; Ramankutty, N.; Foley, J.A. Closing yield gaps through nutrient and water management. Nature 2012, 490, 254-257. [CrossRef] [PubMed]

17. Basra, A. Plant Growth Regulators in Agriculture and Horticulture: Their Role and Commercial Uses; CRC Press: Boca Raton, FL, USA, 2000.

18. Shah, S.H.; Ahmad, I. Samiullah Effect of gibberellic acid spray on growth.; nutrient uptake and yield attributes during various growth stages of black cumin (Nigella sativa L.). Asian J. Plant Sci. 2006, 5, 881-884.

19. Hedden, P.; Sponsel, V. A Century of Gibberellin Research. J. Plant Growth Regul. 2015, 34, 740-760. [CrossRef] [PubMed]

20. Azuma, T.; Ueno, S.; Uchida, N.; Yasuda, T. Gibberellin-induced elongation and osmoregulation in internodes of floating rice. Physiol. Plant. 1997, 99, 517-522. [CrossRef]

21. Bhaskar, S.; Vasantha Kumar, T.; Srivastava, H.C. Influence of growth regulators on production of herbage and oil in patchouli (Pogostemon patchouli). Ind. Perfum. 1997, 41, 98-101.

22. Brock, T.G. Combined effects of hormones and light during growth promotion in primary leaves of Phaseolus vulgaris. Can. J. Bot. 1993, 71, 501-505. [CrossRef]

23. Emongor, V.E. Effect of benzyladenine and gibberellins on growth, yield and yield components of common bean (Phaseolus vulgaris). UNISWA. Res. J. Agric. Sci. Technol. 2002, 6, 65-72. [CrossRef]

24. Gupta, V.N.; Datta, S.K. Influence of gibberellic acid on growth and flowering in chrysanthemum (Chrysanthemum morifolium Ramat) cv. Jayanti. Ind. J. Plant Physiol. 2001, 6, 420-422.

25. Khan, N.A. Samiullah Comparative effect of modes of gibberellic acid application on photosynthetic biomass distribution and productivity of rapeseed-mustard. Physiol. Mol. Biol. Plants 2003, 9, 141-145.

26. Richards, D.E.; King, K.E.; Ait-Ali, T.; Harberd, N.P. How gibberellin regulates plant growth and development: A molecular genetic analysis of gibberellin signaling. Annu. Rev. Plant Biol. 2001, 52, 67-88. [CrossRef] [PubMed]

27. Takei, K.; Takahashi, T.; Sugiyama, T.; Yamaya, T.; Sakakibara, H. Multiple routes communicating nitrogen availability from roots to shoots: A signal transduction pathway mediated by cytokinin. J. Exp. Bot. 2002, 53, 971-977. [CrossRef] [PubMed]

28. Wareing, P.F.; Phillips, I.D.J. Growth and Differentiation in Plants, 3rd ed.; Pergamon Press: Oxford, UK, 1981.

29. Yang, Y.Z.; Lin, D.C.; Guo, Z.Y. Promotion of fruit development in cucumber (Cucumis sativus) by thidiazuron. Sci. Hortic. 1992, 50, 47-51. [CrossRef]

30. Aharoni, N.; Dvir, O.; Chalupowicz, D.; Aharon, Z. Coping with postharvest physiology of fresh culinary herbs. Acta Hortic. 1993, 344, 69-78. [CrossRef]

31. Ding, Y.; Sheng, J.; Li, S.; Nie, Y.; Zhao, J.; Zhu, Z.; Wang, Z.; Tang, X. The role of gibberellins in the mitigation of chilling injury in cherry tomato (Solanum lycopersicum L.) fruit. Postharvest Biol. Technol. 2015, 101, 88-95. [CrossRef]

32. Valero, D.; Serrano, M.; Burló, F.; Carbonell, A.; Burgos, L.; Riquelme, F.; Martinez-Romero, D.; Martínez-Romero, D. Exogenous Polyamines and Gibberellic Acid Effects on Peach (Prunus persica L.) Storability Improvement. J. Food Sci. 2000, 65, 288-294.

33. Yu, T.; Wu, P.G.; Qi, J.J.; Zheng, X.D.; Jiang, F.; Zhan, X. Improved control of postharvest blue mold rot in pear fruit by a combination of Cryptococcus laurentii and gibberellic acid. Biol. Control 2006, 39, 128-134. [CrossRef]

34. Robert, E.C. Introduction: Nature, Occurrence and Functioning of Plant Hormones. In Biochemistry and Molecular Biology of Plant Hormones; Hooykaas, P.J.J., Hall, M.A., Libbenga, K.R., Eds.; Elsevier: Amsterdam, The Netherlands; New York, NY, USA; London, UK, 1999; pp. 3-22.

35. Janick, J. Horticultural Science; Freeman \& Co.: San Francisco, CA, USA, 1979.

36. Khan, M.M.A.; Gautam, C.; Mohammad, F.; Siddiqui, M.H.; Naeem, M.; Khan, M.N. Effect of gibberellic acid spray on performance of tomato. Turk. J. Biol. 2006, 30, 11-16.

37. Khan, N.A.; Ansari, H.R. Samiullah Effect of gibberellic acid spray during ontogeny of mustard on growth, nutrient uptake and yield characteristics. J. Agron. Crop Sci. 1998, 181, 61-73. [CrossRef]

38. King, R.W.; Evans, L.T. Gibberellins and flowering of grasses and cereals: Prizing open the lid of the "florigen black box". Annu. Rev. Plant Biol. 2003, 54, 307-328. [CrossRef] [PubMed] 
39. Mukherjee, R.K.; Prabhakar, B.S. Effect of gibberellin on rice yield response to nitrogen applied at heading, and quality of seeds. Plant Soil 1980, 55, 153-156. [CrossRef]

40. Pal, P.; Yadav, K.; Kumar, K.; Singh, N. Effect of Gibberellic Acid and Potassium Foliar Sprays on Productivity and Physiological and Biochemical Parameters of Parthenocarpic Cucumber cv. 'Seven Star F1'. J. Hortic. Res. 2016, 24, 93-100. [CrossRef]

41. Singh, S.P. Response of tomatoes to growth substances-A review. Adv. Hort. Forest. 1995, 4, 73-84.

42. Miceli, A.; Moncada, A.; Sabatino, L.; Vetrano, F. Effect of Gibberellic Acid on Growth, Yield, and Quality of Leaf Lettuce and Rocket Grown in a Floating System. Agronomy 2019, 9, 382. [CrossRef]

43. Sonneveld, C.; Voogt, W. Plant Nutrition of Greenhouse Crops; Springer Science and Business Media LLC: Berlin, Germany, 2009.

44. Goto, E.; Both, A.; Albright, L.; Langhans, R.; Leed, A. Effect of dissolved oxygen concentration on lettuce growth in floating hydroponics. Acta Hortic. 1996, 440, 205-210. [CrossRef]

45. McGuire, R.G. Reporting of Objective Color Measurements. HortScience 1992, 27, 1254-1255. [CrossRef]

46. Merck Reagenti, Prodotti Chimici e Attrezzature per il Laboratorio. Available online: http://www. merckmillipore.com/chemicals (accessed on 28 May 2019).

47. Hooley, R. Gibberellins: Perception, transduction and responses. Plant Mol. Biol. 1994, 26, $1529-1555$. [CrossRef]

48. Da Silva Vieira, M.R.; Citadini, V.; Lima, G.P.P.; de Souza, A.V.; de Souza Alves, L. Use of gibberellin in floriculture. Afr. J. Biotechnol. 2010, 9, 9118-9121.

49. Khan, N.A.; Mir, R.; Khan, M.; Javid, S.; Samiullah. Effects of gibberellic acid spray on nitrogen yield efficiency of mustard grown with different nitrogen levels. Plant Growth Regul. 2002, 38, 243-247. [CrossRef]

50. Shah, S.H. Effects of salt stress on mustard as affected by gibberellic acid application. Gen. Appl. Plant Physiol. 2007, 33, 97-106.

51. Gelmesa, D.; Abebie, B.; Desalegn, L. Effects of Gibberellic acid and 2, 4-dichlorophenoxyacetic acid spray on fruit yield and quality of tomato (Lycopersicon esculentum Mill.). J. Plant Breed. Crop Sci. 2010, 2, 316-324.

52. Ludford, P.M. Postharvest Hormone Changes in Vegetables and Fruit. In Plant Hormones; Davies, P.J., Ed.; Kluwer Academic Publishers: Dordrecht, NL, USA, 1995.

53. Tang, X.M.; Liu, C.; Zhong, R.C.; Jiang, J.; Han, Z.Q.; He, L.Q.; Li, Z.; Xiong, F.Q.; Tang, R.H. Comparative studies on the chemical regulation of peanuts by paclobutrazol, mepiquat chloride and chlorocholine chloride. J. South. Agric. 2011, 42, 603-605.

54. Xie, B.T.; Wang, Q.M.; Zhang, H.Y.; Li, A.X.; Hou, F.Y.; Wang, B.Q.; Dong, S.X.; Zhang, L.M. The effect of plant growth regulators on the yield and phytohormone concentration in sweet potato. Acta Agric. Boreali Sin. 2016, 31, 155-161.

55. Zhang, Y. Research status of plant growth regulators on crop regulation. Mod. Agric. 2016, 5, 31-34.

56. Han, H.Y.; Wang, F.A.; Chen, B.; Li, B.A.; Zhang, W.F.; Tian, X.L.; Li, Z. Effect of nitrogen fertilizer on plant growth and yield formation of cotton applied with fortified DPC. J. China Agric. Univ. 2017, 22, 12-20.

57. Zhang, M.; Liu, M.; Zhang, Y.; Ji, Y.; Zhao, M.; Wu, Z. Effect of different plant growth regulator added in nutrient solution on growth and development of summer tomato seedling. North Hortic. 2017, 6, 8-13.

58. Khan, N.A. Effect of gibberellic acid on carbonic anhydrase, photosynthesis, growth and yield of mustard. Biol. Plant. 1996, 38, 145-147. [CrossRef]

59. Sültemeyer, D.; Schmidt, C.; Fock, H.P. Carbonic anhydrases in higher plants and aquatic microorganisms. Physiol. Plant. 1993, 88, 179-190. [CrossRef]

60. Khan, N.A. Variation in carbonic anhydrase activity and its relationship with photosynthesis and dry mass of mustard. Photosynthetica 1994, 30, 317-320.

61. Roura, S.I.; Davidovich, L.A.; Del Valle, C.E. Postharvest changes in fresh Swiss chard (Beta vulgaris. type cycla) under different storage conditions. J. Food Qual. 2000, 23, 137-147. [CrossRef]

62. Roura, S.I.; Davidovich, L.A.; Del Valle, C.E. Quality loss in minimally processed Swiss chard related to amount of damaged area. Lebensm. Wiss. Technol. 2000, 33, 53-59. [CrossRef]

63. Hodges, D.M.; Toivonen, P.M. Quality of fresh-cut fruits and vegetables as affected by exposure to abiotic stress. Postharvest Biol. Technol. 2008, 48, 155-162. [CrossRef]

64. Toivonen, P.M.A.; DeEll, J.R. Physiology of fresh-cut fruits and vegetables. In Physiology of Fresh-Cut Fruits and Vegetables: Science, Technology, and Market; Lamikanra, O., Ed.; CRC Press: Boca Raton, FL, USA, 2002; pp. 91-123. 
65. Alfonzo, A.; Gaglio, R.; Miceli, A.; Francesca, N.; Di Gerlando, R.; Moschetti, G.; Settanni, L. Shelf life evaluation of fresh-cut red chicory subjected to different minimal processes. Food Microbiol. 2018, 73, $298-304$. [CrossRef]

66. Miceli, A.; Gaglio, R.; Francesca, N.; Ciminata, A.; Moschetti, G.; Settanni, L. Evolution of shelf life parameters of ready-to-eat escarole (Cichorium endivia var. latifolium) subjected to different cutting operations. Sci. Hortic. 2019, 247, 175-183. [CrossRef]

67. Miceli, A.; Miceli, C. Effect of Nitrogen Fertilization on the Quality of Swiss Chard at Harvest and during Storage as Minimally Processed Produce. J. Food Qual. 2014, 37, 125-134. [CrossRef]

68. Miceli, A.; Romano, C.; Moncada, A.; D'Anna, F.; Vetrano, F. Effect of cold storage on the quality of minimally processed cauliflower. Carpath. J. Food Sci. Technol. 2015, 7, 70-74.

69. Watada, A.E.; Qi, L. Quality of fresh-cut produce. Postharv. Biol. Technol. 1999, 15, 201-205. [CrossRef]

70. Demirsoy, L.; Bilgener, S. The effect of chemical applications on cuticular and epidermal properties of some sweet cherry cultivars with respect to fruit cracking susceptibility. Turk. J. Agric. For. 2000, 24, 541-550.

71. Sams, C.E. Preharvest factors affecting postharvest texture. Postharvest Biol. Technol. 1999, 15, $249-254$. [CrossRef]

72. Gang, C.; Li, J.; Chen, Y.; Wang, Y.; Li, H.; Pan, B.; Odeh, I. Synergistic effect of chemical treatments on storage quality and chilling injury of honey peaches. J. Food Process. Preserv. 2015, 39, 1108-1117. [CrossRef]

73. Miceli, A.; Vetrano, F.; Romano, C. Effect of hot air treatment on minimally processed cauliflower. Acta Hortic. 2013, 1005, 309-314. [CrossRef]

74. Lers, A.; Jiang, W.; Lomaniec, E.; Aharoni, N. Gibberellic Acid and $\mathrm{CO}_{2}$ Additive Effect in Retarding Postharvest Senescence of Parsley. J. Food Sci. 1998, 63, 66-68. [CrossRef]

75. Gaglio, R.; Miceli, A.; Sardina, M.T.; Francesca, N.; Moschetti, G.; Settanni, L. Evaluation of microbiological and physico-chemical parameters of retail ready-to-eat mono-varietal salads. J. Food Process. Preserv. 2019, 43, e13955. [CrossRef]

76. Jacob, R.A.; Sotoudeh, G. Vitamin C Function and Status in Chronic Disease. Nutr. Clin. Care 2002, 5, 66-74. [CrossRef]

77. Eheart, M.S.; Odland, D. Storage of fresh broccoli and green beans. J. Am. Diet. Assoc. 1972, 60, 402-406.

78. Esteve, M.J.; Farré, R.; Frígola, A.; Clemente, G. Changes in Ascorbic Acid Content of Green Asparagus during the Harvesting Period and Storage. J. Agric. Food Chem. 1995, 43, 2058-2061. [CrossRef]

79. Howard, L.; Wong, A.; Perry, A.; Klein, B. $\beta$-Carotene and Ascorbic Acid Retention in Fresh and Processed Vegetables. J. Food Sci. 1999, 64, 929-936. [CrossRef]

80. Wu, Y.; Perry, A.K.; Klein, B.P. Vitamin C and B-carotene in fresh and frozen green beans and broccoli in a simulated system. J. Food Qual. 1992, 15, 87-96. [CrossRef]

81. El-Hamahmy, M.A.; Elsayed, A.I.; Odero, D.C. Physiological effects of hot water dipping, chitosan coating and gibberellic acid on shelf-life and quality assurance of sugar snap peas (Pisum sativum L. var. macrocarpon). Food Packag. Shelf Life 2017, 11, 58-66. [CrossRef]

82. Lee, S.K.; Kader, A.A. Preharvest and postharvest factors influencing vitamin C content of horticultural crops. Postharvest Biol. Technol. 2000, 20, 207-220. [CrossRef]

83. Stefanelli, D.; Goodwin, I.; Jones, R. Minimal nitrogen and water use in horticulture: Effects on quality and content of selected nutrients. Food Res. Int. 2010, 43, 1833-1843. [CrossRef]

84. Mozafar, A. Plant Vitamins. Agronomic, Physiological and Nutritional Aspects; CRC Press: Boca Raton, FL, USA, 1994.

85. European Union Commission Regulation (EC) No. 1258/2011 of 2 December 2011 amending Regulation (EC) No. 1881/2006 as regards maximum levels for nitrates in foodstuffs. Off. J. Eur. Union 2011, L320, 15-17.

86. Chanda, S.V.; Sood, C.R.; Reddy, V.S.; Singh, Y.D. Influence of plant growth regulators on some enzymes of nitrogen assimilation in mustard seedlings. J. Plant Nutr. 1998, 21, 1765-1777. [CrossRef]

87. Moncada, A.; Miceli, A.; Sabatino, L.; Iapichino, G.; D'Anna, F.; Vetrano, F. Effect of Molybdenum Rate on Yield and Quality of Lettuce, Escarole, and Curly Endive Grown in a Floating System. Agronomy 2018, 8, 171. [CrossRef]

88. La Scalia, G.; Aiello, G.; Miceli, A.; Nasca, A.; Alfonzo, A.; Settanni, L. Effect of vibration on the quality of strawberry fruits caused by simulated transport. J. Food Process Eng. 2016, 39, 140-156. [CrossRef] 
89. Ihl, M.; Shene, C.; Scheuermann, E.; Bifani, V. Correlation for pigment content through color determination using tristimulus values in a green leafy vegetable, Swiss chard. J. Sci. Food Agric. 1994, 66, 527-531. [CrossRef]

90. Madeira, A.C.; Ferreira, A.; De Varennes, A.; Vieira, M.I. SPAD Meter Versus Tristimulus Colorimeter to Estimate Chlorophyll Content and Leaf Color in Sweet Pepper. Commun. Soil Sci. Plant Anal. 2003, 34, 2461-2470. [CrossRef]

91. Aharoni, N.; Back, A.; Ben-Yehushua, S.; Richmond, A.E. Exogenous gibberellic acid and the cytokinin isopentenyladenine retardants of senescence in romaine lettuce. J. Am. Soc. Hortic. Sci. 1975, 100, 4-6.

92. Aharoni, N. Interrelationship between ethylene and growth regulators in the senescence of lettuce leaf discs. J. Plant Growth Regul. 1989, 8, 309-317. [CrossRef]

93. Misra, A.N.; Biswal, U.C. Effect of phytohormones on chlorophyll degradation during aging of chloroplasts in vivo and in vitro. Protoplasma 1980, 105, 1-8. [CrossRef]

94. Chin, T.Y.; Beevers, L. Changes in endogenous growth regulators in Nasturtium leaves during senescence. Planta 1970, 92, 178-188. [CrossRef]

95. Li, J.R.; Yu, K.; Wei, J.R.; Ma, Q.; Wang, B.Q.; Yu, D. Gibberellin retards chlorophyll degradation during senescence of Paris polyphylla. Biol. Plant. 2010, 54, 395-399. [CrossRef]

96. Van Doorn, W.G.; Van Lieburg, M.J. Interaction between the effects of phytochrome and gibberellic acid on the senescence of Alstroemeria pelegrina leaves. Physiol. Plant. 1993, 89, 182-186. [CrossRef]

97. Cefola, M.; Carbone, V.; Minasi, P.; Pace, B. Phenolic profiles and postharvest quality changes of fresh-cut radicchio (Cichorium intybus L.): Nutrient value in fresh vs. stored leaves. J. Food Compos. Anal. 2016, 51, 76-84. [CrossRef]

(C) 2019 by the authors. Licensee MDPI, Basel, Switzerland. This article is an open access article distributed under the terms and conditions of the Creative Commons Attribution (CC BY) license (http://creativecommons.org/licenses/by/4.0/). 